\title{
Financial Stability Analysis in Banking Sector: A Stress Test
}

Method*

Çağatay BAŞARIR**

Cengiz TORAMAN ${ }^{* * *}$

\section{ABSTRACT}

Stability of the financial sector is a matter of debate nowadays. Notably, decision of capital investing in order to hedge against various types of risks is a major problem for the banks. At this phase, stress testing is a basic method to determine whether the capital ratios of the banks are adequate or not.

Stress testing, naming in the context of FSAP (Financial Sector Assessment Program)

for the first time, was included in the financial stability reports of the developed countries especially in the parts of financial analysis issues. Firstly, they only took part in FSAP partially; thereafter they were used as a tool for financial sector stability analysis by regularity organizations like IMF (International Monetary Fund) and World Bank and also by senior management. Being used for the financial analysis of the banking sector especially in the developing countries like Turkey, stress tests will be analyzed theoretically in this study.

Anahtar Kelimeler: Banking Sector, Financial Stability, Risk Management, Stress Tests.

JEL Sinıflandırması: G17, G21, C53.

\section{Bankacıllk Sektörü Finansal İstikrar Analizleri: Stres Testi Metodu}

\section{$\ddot{O Z Z E T}$}

Günümüzde bankacılık sektörü için finansal istikrar konusu çok tartışılan bir konudur. Özellikle bankaların değişik risklere karşı ne kadar sermaye ayırmaları gerektiği hususu bankalar için önemli bir sorundur. Işste bu aşamada, olası krizler karşısında bankaların bulundurdukları sermaye miktarlarının yeterli olup olmadığını tespit etmede temel tekniklerden biri stres testleridir.

1999 yılında IMF ve Dünya Bankası'nın ortaklaşa gerçekleştirdiği FSAP (Finansal Sektör Değerlendirme Programı) kapsamında ilk defa dile getirilen stres testleri daha sonra gelişmiş ülkelerin finansal istikrar raporlarında özellikle risk analizi kısımlarında geniş yer bulmaya başladl. Başlarda sadece, FSAP'in bir bölümünde kendine yer edinen stres testleri, daha sonra IMF (Uluslararası Para Fonu) ve Dünya Bankası gibi düzenleyici kuruluşlar ve üst düzey yöneticiler tarafindan finansal istikrar analizlerinin yapılmasında bir araç olarak kullanılmaya başlandı. Çalışmada bankacılık sektörünün finansal istikrarının analizlerinde kullanılan ve özellikle ülkemiz gibi gelişmekte olan ülkeler için yeni bir yaklaşım olan stres testleri kuramsal açıdan incelenecektir.

Keywords: Bankacılık Sektörü, Finansal İstikrar, Risk Yönetimi, Stres Testleri.

Jel Classification: G17, G21, C53.

\footnotetext{
* This Study is derived from doctoral thesis of Çağatay Başarır, under the name of "Analysis Of Turkish Banking Sector Financial Stability With Stress Testing”

** Dr. Çağatay Başarır, Balıkesir University, Bandırma Vocational School, cbasarir@balikesir.edu.tr

*** Prof. Dr. Cengiz Toraman, Gaziantep University, Faculty of Economics and Administrative Science, cengiztoraman2004@yahoo.com
} 


\section{INTRODUCTION}

In the economics-finance literature, there are some definitions of financial stability including all kinds of financial difficulty, as well as the definitions focusing only leakages disrupting the financial system operations. While some approaches emphasize the stability of the system against external shocks, some others evaluate the financial system as the source of shocks.

According to Financial Stability Report (2005) prepared by the CBT (Central Bank of Turkey), the financial stability is the stability and resistance of financial markets, financial institutions and payment systems against shocks. Thus, financial system operates sturdily and steadily, thereby, economic resources can be allocated productively and risks can be managed and spread properly.

Determination and prediction of the factors affecting the financial stability is important for sustainability of financial stability. At this stage, reasons causing financial stability should be detected. If factors causing the financial instability are determined correctly, better precautions can be taken.

Systematic risk factors such as an increase in interest rates, deterioration of bank's balance sheets, collapse of stock exchange and rising uncertainty are considered as the main reasons causing financial instability. Main reason of the deterioration of bank's balance sheets is risky loans. In the following phases of financial instability, loan losses are expected to increase due to the crises and the economic recession. More deterioration of bank's balance sheets causes the crisis to expand and deepen (Altıntaş, 2012: 17).

Main tools in order to analysis financial stability is the traditional factors: macroeconomic forecast and early warning indicators; and also stress testing that is a new approach used especially for the determination of banks capital adequacy in the developing countries.

\section{MAIN TOOLS OF FINANCIAL STABILITY ANALYSIS}

Financial stability can be defined as cycle of financial system between stability and instability border. Financial sector analysis aims to determine the threats challenged by the financial sector and create appropriate political interventions (Schinasi, 2004: 8).

Determination and forecasting of factors affecting the financial stability is important in order to maintain the stability. At this phase, what causes financial instability should be specified. Once this is specified, more effective precautions can be taken. Increase of interest rates, deterioration of bank's balance sheets, collapse of stock exchange and rising uncertainty are considered as the main reasons causing financial instability. Main reason of deterioration of bank's balance sheet is risky loans.

Tools in order to analysis financial stability are traditional tools and a contemporary tool: stress testing. 


\subsection{Traditional Tools}

Traditional tools are macroeconomic forecasting and early warning indicators.

\section{Macroeconomic Forecasting:}

Macroeconomic forecasting is the analysis of future performance of some past macro economic data using forecasting. Macroeconomic forecasting models can be used in stress testing process as a part of scenario analysis.

Macroeconomic forecasting model can basically be defined as follows:

$$
E\left(\tilde{X}_{t+1}\right)=g_{1}\left\{X^{t}, Z^{t}\right\}
$$

In this equation, unknown value of a random variable is referred by tilde, past realization of random variable to the t time is referred as $t$. Main difficulty of this method is estimating a function implying the past realization of random macroeconomic variable $\mathrm{X}$ and expected values of the other relevant variables referred by Z. Best estimations for the whole economy or a specific sector (for instance financial sector) are largely derived from the past values of data (Sorge, 2004: 3).

\section{Early Warning Indicators:}

Early warning indicators are different from the macroeconomic forecasting approach depending on exceptional but probable incidences. This approach aims to create unexpected precautions about the probable problems that may occur. Early warning indicators include indicators in order to help to estimate unexpected crisis probabilities. These indicators define the crisis determining the threshold level of macroeconomic variables and estimate the breaking point of these thresholds.

Early warning indicator models can be defined as follows using the same terms of macroeconomic forecasting models:

$$
P\left(\tilde{X}_{t+1} \geq \bar{X}\right)=g_{2}\left\{X^{t}, Z^{t}\right\}
$$

In this equation, subsets of $\mathrm{X}$ and $\mathrm{Z}$ are determined as the main indicators of crises possibility. Crisis is defined as a dual incidence when the threshold values of macroeconomic variables $(\mathrm{X})$ are exceeded from that level (For instance, while $\widetilde{X}_{t+1} \geq \bar{X}$ refers to a crisis, the other possibility refers no crisis) (Sorge, 2004: 4).

Some properties of macroeconomic forecasting and early warning indicators are similar, while there are also some differences. Different from macroeconomic forecasting approach, early warning indicators and stress tests depends on exceptional but probable incidences. Early warning indicators usually rely on historical data. Stress tests should rely on historical data or hypothetical scenarios. Stress tests analysis the consequences of crisis according to financial stability, not the probability of crisis. 


\subsection{Stress Testing}

Stress testing is a method used to measure the fragility of a portfolio or the whole financial system against various hypothetical scenarios. Stress testing is a "what if ?" approach estimating what should happen to the capital, profit or cash flow of a company or the whole system if certain risks are realized. This method means further than a simple numeric calculation of probable shocks. Stress tests usually evaluate the financial performance of financial institutions due to their financial solvency and liquidity (Vinals, 2012: 8).

In general, stress tests can be referred as a risk measurement technique to measure the loss when an infrequent but probable risk takes place.

Stress tests can be classified into four categories according to their purposes: Macroprudential, microprudential, crisis management and internal risk management. Macroprudential (surveillance) stress tests analysis the vulnerability of the whole financial system. The other category is microprudential stress (supervisory) test that portfolio of financial institutions re tested and evaluated due to their own risk management systems. Third category of stress testing aims at crisis management. Main purpose of crisis management is providing inputs to recapitalize the banks and building re-structuring plans. The last category is the stress tests to aim internal risk management. Banks that use stress testing as a part of their internal risk management tool intend to manage risks of their existing portfolio, gain data to make a regular workflow plan (Vinals, 2012: 11-12).

While the stress tests in FSAP, GFSR (Global Financial Stability Report) and Financial Stability Reports are examples of macro prudential stress testing, CEBS(The Committee of European Banking Supervisors) / EBA (European Banking Authority) stress tests made by CCAR (Comprhensive Capital Analysis), Basel are examples of micro prudential stress tests. An example of internal risk control stress testing is Riskmetrics.

\subsubsection{Macro Economic Stress Tests}

Spread of shocks among the economy is shown in Figure 1. (Haldane and et al,2007:

$5)$.

When we look at the figure, we can see that the first shock reveals the reel or the financial fragilities of the economy. This shock can sometimes be a result of some specific companies or sometimes can arise from macroeconomic instabilities or shortages affecting the system as a whole.

Effects of the shock can be seen on financial sector directly or indirectly whatever characteristics it has. When a shock realizes households, companies, public, banks, other financial institutions and the market infrastructure are affected according to the property of it (micro or macro). First effects of the shock on the banks are firstly credit, market and liquidity risk and the contagion and other risks are seen. But, these are not the only loss 
caused by the crisis. In addition, correlation among the different types of risks increases the total losses, destroying the profit and capital ratios and makes more pressure on banks. Furthermore, feedback effects can cause financial crisis spread into the real sector. Financial instruments corrupts with the adverse scenario, decrease the credits that feed the real economy.

Figure 1: A General Look at the Macroeconomic Stres Tests

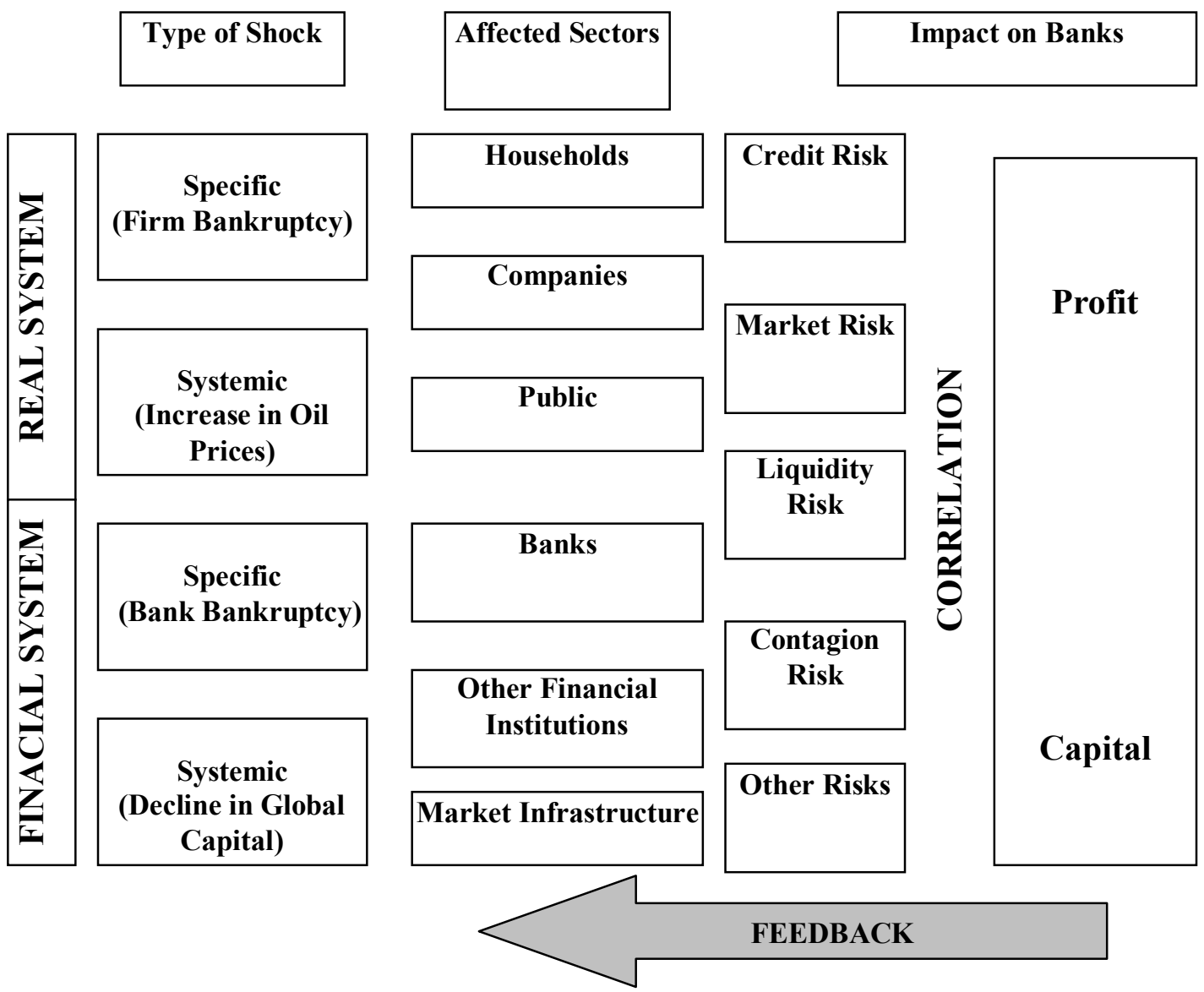

Source: Quagliariello, M.(2009). Stres Testing The Banking System. Methodologies and Applications. New Yok. Cambridge University Pres. p. 21.

Research part of the macroeconomic stress testing can be divided into 4 categories: identification of specific vulnerabilities or areas of concern, construction of a scenario in the context of a consistent macroeconomic framework, The next step is to perform the numerical analysis, consider any second round effects and the last part is interpretative part (Jones and et al., 2004: 6). This process includes many participants. Main participants of the stress testing can be seen in Figure 2. 
When we look at Figure 2, we see that the first part includes the selection of most related financial tools and validity of the data. Secondly, main vulnerabilities of the financial system and the fundamental risks are determined and the real stress points are detected. In addition, some assumptions must be made in this phase in order to evaluate the intensity and probability of the risks and conversion of shocks to appropriate scenarios.

Figure 2: Main Participants of the Stress Testing
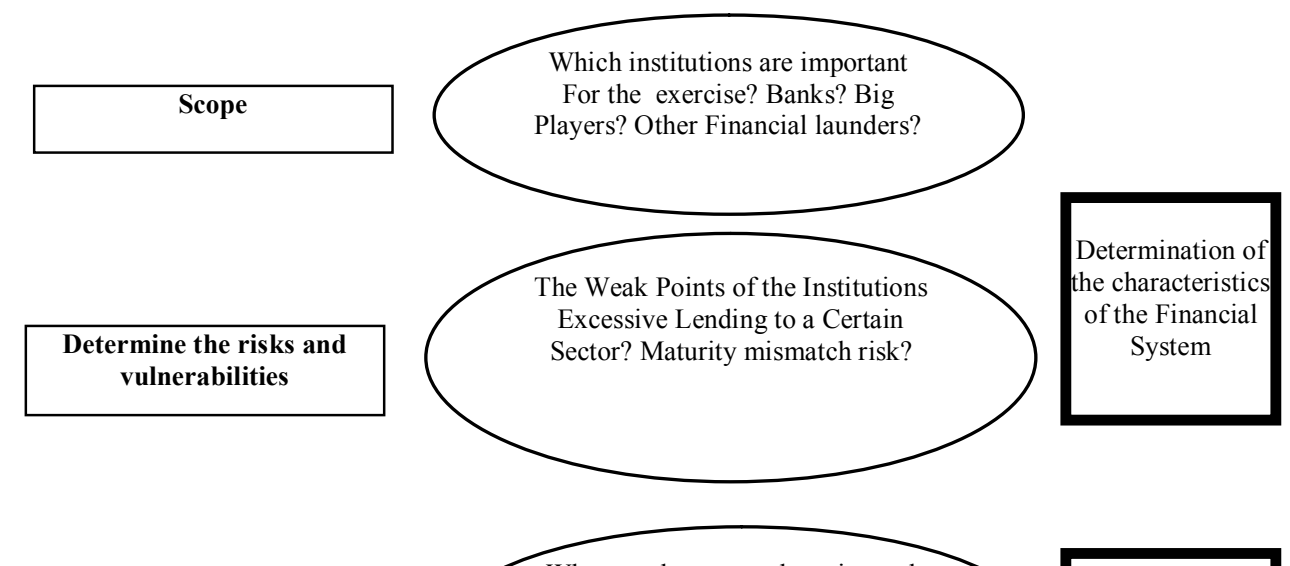

Excessive Lending to a Certain
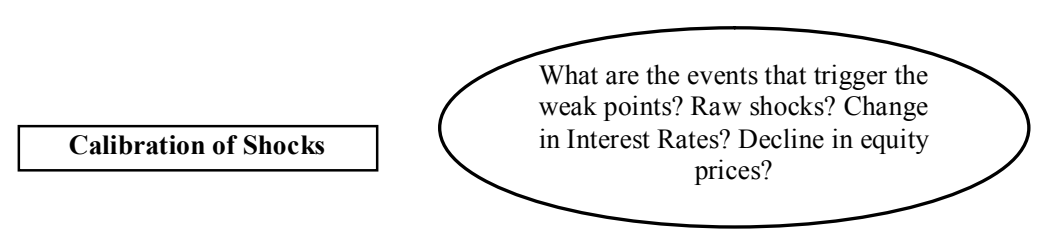

Historical,

Hypothetical,

Reverse

enginering

approaches

\begin{tabular}{|c|}
\hline $\begin{array}{c}\text { Implementation of the } \\
\text { Scenario }\end{array}$ \\
\hline
\end{tabular}
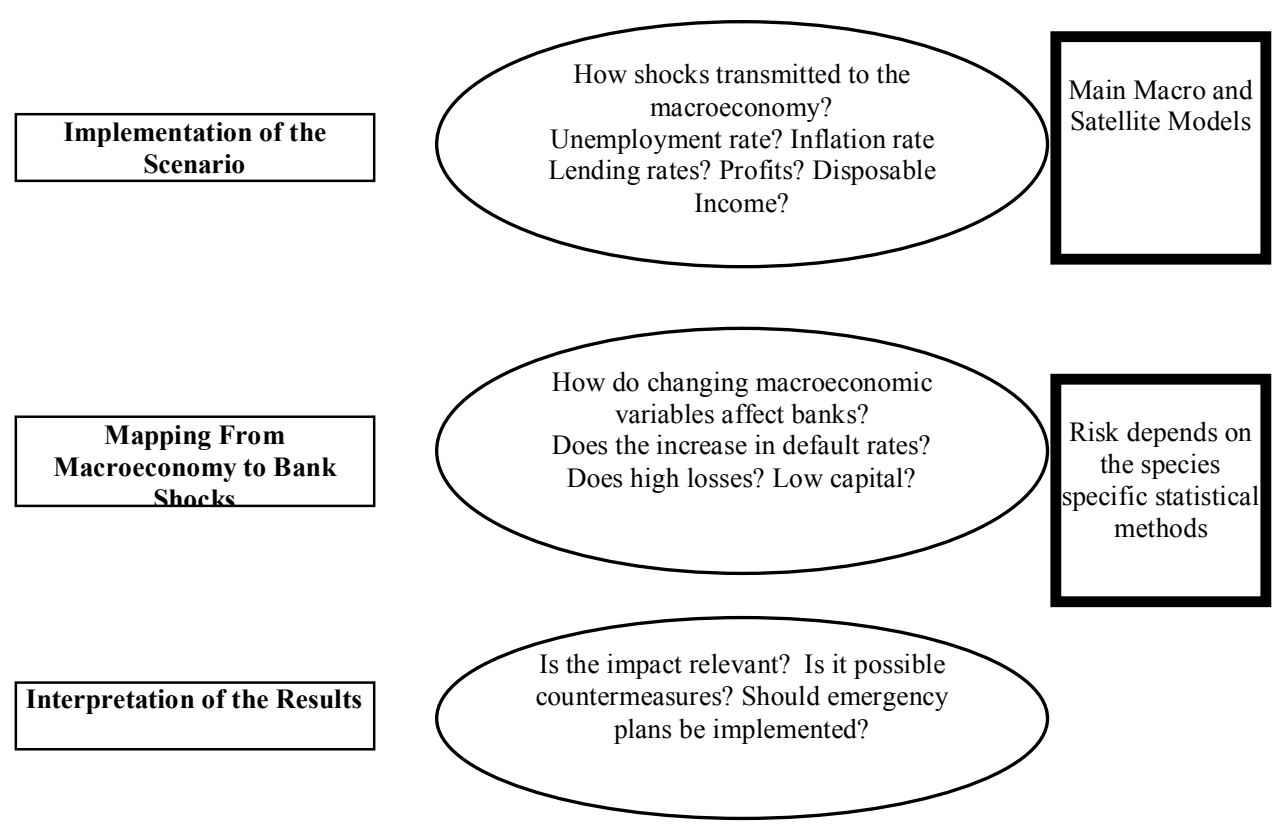

Source: Quagliariello, M. (2009). Stres Testing The Banking System. Methodologies and New York. Cambridge University Pres. p. 26.

Applications. 
At the fourth part, statistical method to measure the effects of changing economic environment on banks' portfolio should be chosen and developed. Simulation methods are selected at this last part. These results are used as a guide to probable political reactions. All these steps provide the validity of the stress test (Quagliariello, 2009: 25).

\subsubsection{Macro Economic Stress Test Model}

In a macroeconomic stress testing model, a forward looking and internally consistent framework is build using a macro model to analysis the interactions between financial system and real economy.

Steps of building a stress testing model is as follows:

Shock assumptions fort he economy should be introduced.

Using a macroeconomic model, interactions between the macroeconomic variables should be revealed.

Macroeconomic variables should be related to bank's balance sheets using satellite model

Finally, affects of shocks on banks' financial performance should be determined and probable effects should be estimated using minimum capital adequacy ratio.

Figure 3. Stres Testing Framework

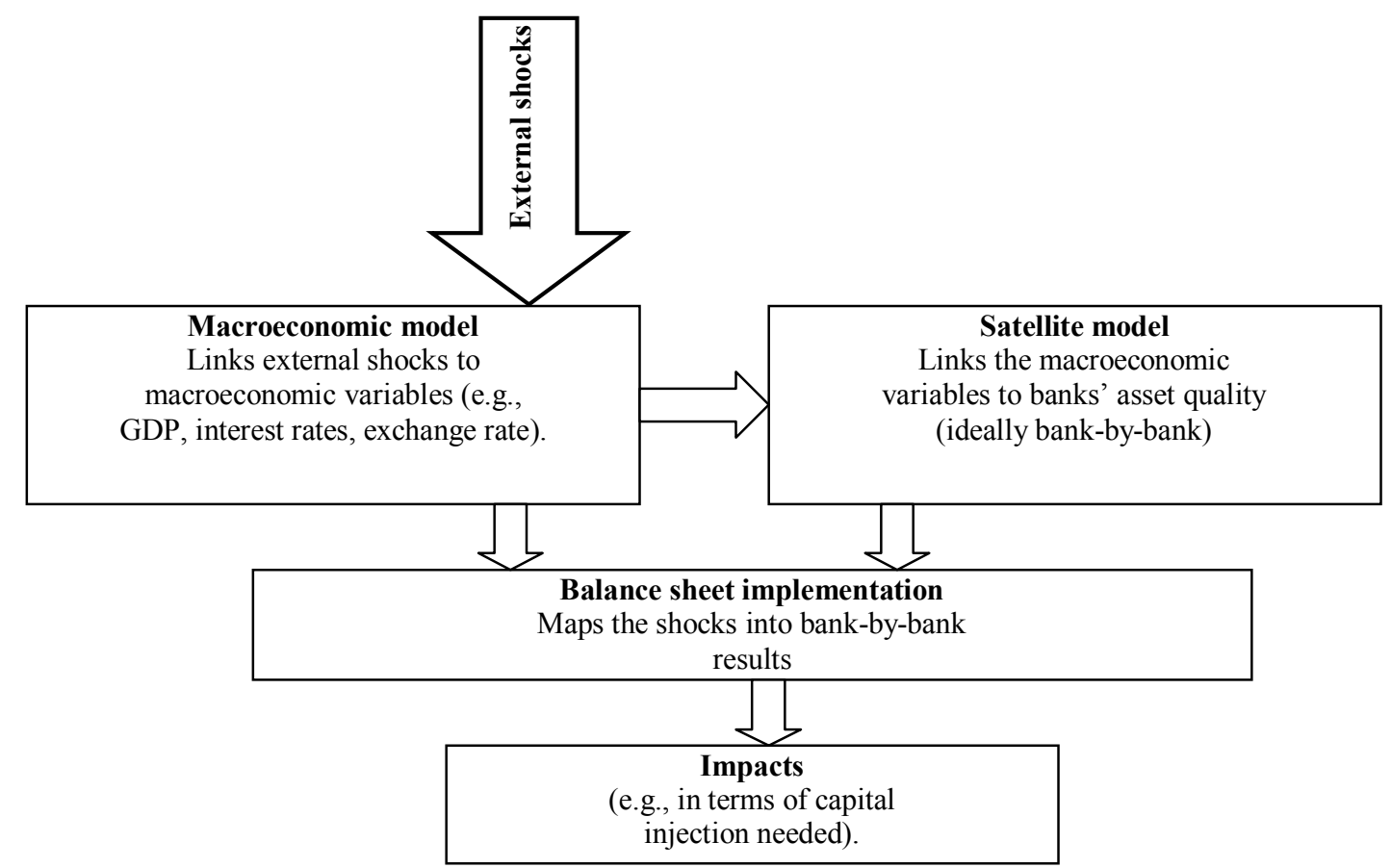

Source: Cihak, M. (2007). Introduction to Applied Stress Testing. Washington DC: International Monetary Fund. IMF Working Paper. p. 8. 
In figure 3, interactions between GDP(Gross Domestic Product), interest rates, exchange rates and the other main economic variables are revealed using a macro model. Medium-scale macro models (such as models used by Central Banks for macroeconomic forecasts) including many different estimated or calibrated relationships are generally used for this purpose. When it is not possible to use this kind of models, VAR (Vector Auto Regressive) or VEC (Vector Error Correction) models can be estimated. A satellite model can also be built for the reason that these models generally include no financial sector variable. Satellite model defines the path between macroeconomic variable and financial sector variables. This type of satellite model can be used for a bank in a specific period of time. Together with the satellite model, macroeconomic model shows the interaction of assumed external shocks with the shocks of banks' assets (Cihak, 2007: 9).

Main purpose of using a macroeconomic model is to add consistency to an empirical based model linking macro economy and basic vulnerabilities (Jones and et al., 2004: 6). Even though macro models are used, it is important to evaluate the results efficiently. Setting the scenario affects the results of the other steps, validity of the application and the results. Evaluation of the shocked variables depends on the assumptions of the base scenario. These assumptions can a scenario not depending on the last existing variable or a forward looking scenario including the last estimations (Quagliariello, 2009: 29).

As it can be seen in Figure 3, there are two main methods to match the effects of shocks with the macroeconomic model, satellite model and balance sheets: Top down approach and bottom up approach. Bottom up approach, depends mainly on individual portfolios. Top down approach, is used to measure the reactions of consolidated or macro level variables (Jones and et al., 2004: 6-7).

Figure 4 shows the functionality of top down and bottom up approaches. Bottom up approach makes bank based simulations using the variable of that bank in order to determine the effect of these variables on the solvency of the bank. Top down approach makes high level simulations. This method chooses variables that could affect the whole sector and total effect on solvency is determined. Top down approach consolidated variables are used for the forecast. "Top down stress testing method" is beneficial to control the results of "bottom up approach". Stress test results have taken part in the financial stability report of Central Banks of Norway and United Kingdom is two examples of this method.

"Top down approach" can ignore the concentrations and interactions between the institutions as it uses consolidated data that is a disadvantage of it. Thus the risk of spreading a few small institution losses through the market can be ignored (Cihak, 2007: 12).

Bottom up approach considers the individual portfolio of the investigated data. In order to transform the macro economic data into the balance sheet of the financial institutions, macro economic factors should be matched with the risk factors applied to the balance sheets individually (from bottom up). Most of the portfolios have their own financial instruments 
with their prices; therefore, hundreds of market price information should be needed in the process of revaluation. Financial institutions can simply this process by matching every portfolio to smaller portfolios. A system based stress test requires two types of matching: first is the matching of macro economic variables with the common risk factors. The second is matching from the common risk factors towards all the other risk factors in the portfolio.

According to the macro model, all the probable financial variables about the model can be detailed or limited. Several indicators such as interest rates, exchange rates, asset prices, credit risk and quality should be considered when a stress test is applied for a financial institution. For this reason, outputs of the macro model should be supported with additional estimations to include all of these risk factors (Jones and et al., 2004: 20).

\section{Figure 4: Operationalisation Of The "Bottom-Up" And “Top-Down" Approaches}

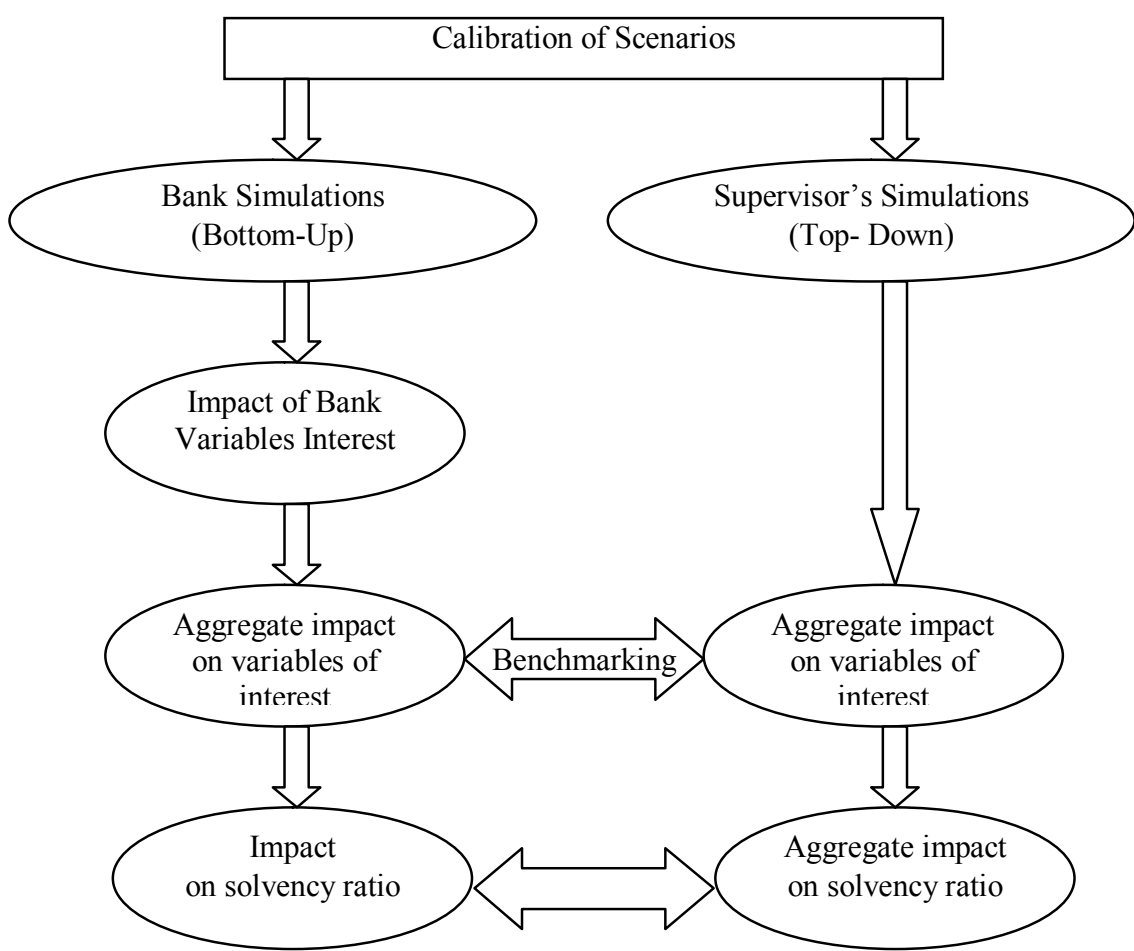

Source: De Bandt, O. and Oung, V. (2004). Assessment of "stress tests" Conducted on the French Banking System. Banque de France Financial Stability Review, 62.

Main advantage of "bottom up approach" is that it can detect the concentration and spread risks thus it can reveal more accurate results. However, it is possible to face with insufficient data problem or calculation difficulties. Detailed information about credit amount the institutions supply for each borrower can provide more certain results but at the same time it can cause calculation problems (Cihak, 2007: 12). 


\subsubsection{Macro Economic Stress Test Models}

Stress tests are commonly used currently, but nevertheless there is no standard classification or measurement method of them. The reason is that the extension of the concept is broad. Certain subtitles can be made according to sub-classification but many methods can be used especially for analysis section.

\section{Figure 5. Stres Testing Techniques}

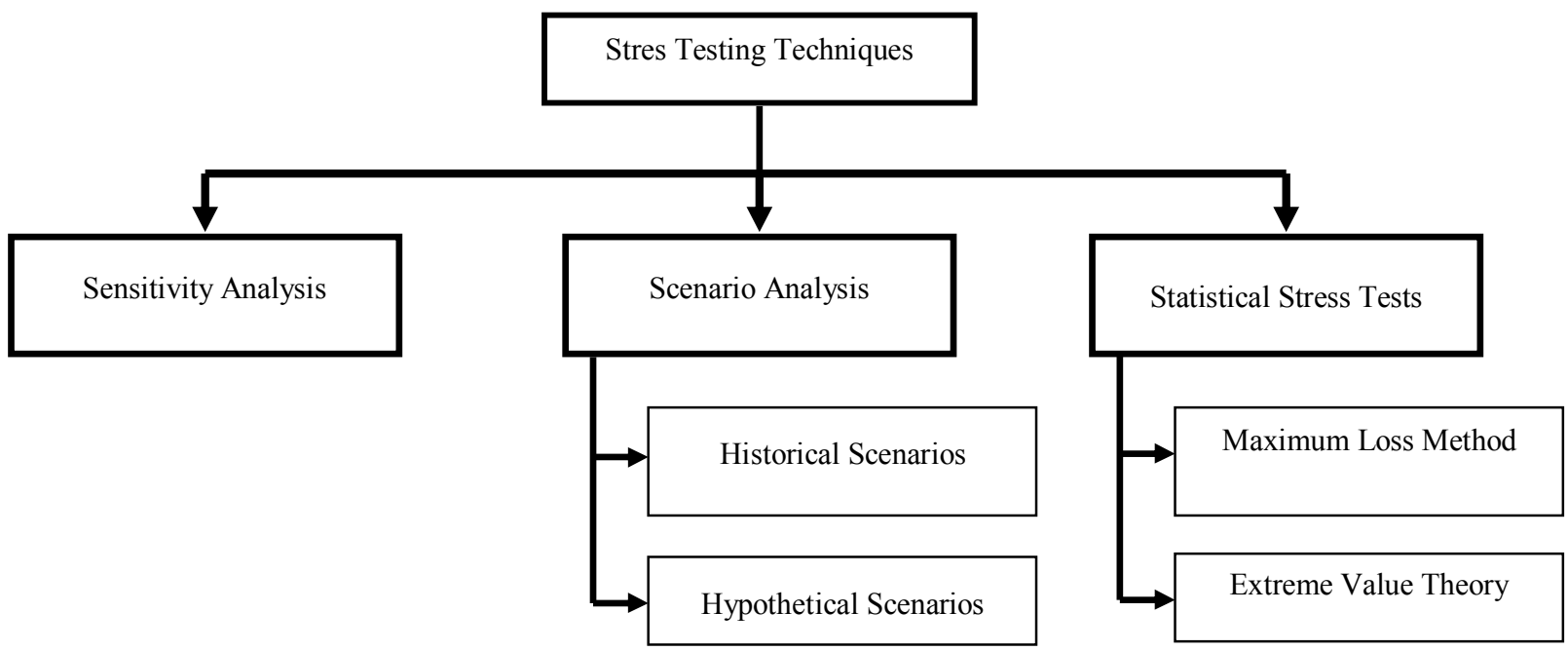

Source: CGFS (2000). Stress Testing By Large Financial Institutions: Current Practice and Aggregation Issues. Bank for International Settlements: 6.

In the Figure 5, techniques of stress testing are classified into three main categories: sensitivity analysis, scenario analysis and statistical stress tests. Scenario analysis is divided into two methods: historical scenario analysis and hypothetic scenario analysis. Statistical scenario analysis is categorized as maximum loss method and extreme value theory.

Sensitivity analysis investigates how the small upper or down movements of the portfolio changes under the influence of different risk factors. This methods is rather easy to apply and can be applied automatically easily. Shocks that are used are situation like a parallel shift in the yield curve as a result of a decrease in overall asset price included in the portfolio. Sensitivity of the assets according to the other assets types in the portfolio can be evaluated with this method (Berry, 2009: 2).

Besides easy application, sensitivity analysis has some disadvantages. Risk managers must consider each shock's optimal size while using this method. In addition, these shock must be re-evaluated in order to not to miss the changes of asset behavior or increasing correlation between two assets. Moreover, this method is narrow-scoped because only one factor is given shock an analysis (Arya, 2008: 8-9). 
Certain scenarios are built and loss- gains are investigated under the assumptions of these scenarios in scenario analysis method. A group of scenario is build under possible changes of variables like stock exchange prices, interest rates, exchange rates in a certain period. Then, cash or accountant values of these variables are determined under each scenario. Scenario analysis is a difficult process. There are not much reference points or rules when scenarios are built.

Scenario should be rational their assumptions should not be inconsistent or unconvincing. In addition, relationships between the variables should be taken into account. All the basic scenarios should totally be included. Scenario analysis does not give information about the possibility of different scenarios. For this reason, validity of different scenarios in practice should be evaluated. Consequently, scenario analysis is a subjective method and depends largely on researcher's skill and ability (Dowd, 2002: 4-5). Scenario analysis are divided into two sub categories. One of them is historical scenario analysis and the other is hypothetical scenario analysis. Historical scenario analysis re-values the portfolio using the values of the portfolio in the past measured incidences. Hypothetic scenario analysis is used in shock structures that has not an example in the past but is possible to happen in the future.

Categories of statistical scenario analysis can be seen in Figure 5. These are maximum loss method and extreme value theory. These two methods include the values of tail area that cannot be measured under stress conditions. Thereby more consistent risk levels are measured. Maximum loss method tests the risk level of an institution by defining a combination of risks that cause the worst loss stimulating the risk factors at most. Results gained by this method are informative but the assumptions should be considered with a great care for a confident analysis (CGFS, 2000: 6-7).

Extreme value theory takes the historical values of uncommon incidences and deduces them to make predictions of the future (Cruz, 2002: 63). For this purpose, historical data that can be defined as "extreme values" are focused and asymptotic distribution of these values are determined.

Basis of the extreme value theory grounds on the works of Fisher\&Tippet (1928), Gnedenko (1943) and Gumbel (1958). It is a branch of order statistics. Applications in finance are newly developed. Extreme value theory helps the modeling of random variables extreme values like the modeling of aggregate random variables by the use of central limit theorem. (Önalan, 2003: 425).

\subsection{Main Tools of Stress Tests}

Selection of stress tests depends on the type of the risk, type of the stress test to perform, the type of shock to apply, the type of scenario to consider; as well as which assets are to be shocked by how much and over what time period (Blaschke and et al., 2001: 11). In this section, main tools of stress tests including the basic risks of the banking sector: interest rate risk, exchange rate risk and credit risk is discussed. 


\subsubsection{Interest Rate Risk}

A financial institution faces interest rate risk when the sensibility of the interest rates of assets and liabilities does not match with each other. An increase in interest rate affects both the return and cost of the interest rate and market value of off balance sheet assests and balance sheet assets (Cihak, 2004b: 3).

There are two methods to measure the interest rate risk depending on the gap between the assets and the liabilities: The Repricing Gap Model, The Maturity Gap Model and also there is a model which take the weighted average of the maturities of assets and liabilities is Duration Model.

The Repricing Gap Model; distributes the interest bearing assets and liabilities due to their repricing time and estimates net interest income according to changes in interest rates using the gap between each liability and asset in a basket.

The Maturity Gap Model; is a model that is weighted in proportion to total market values of an asset and liability and based on the average maturity of this portfolio's assets and liabilities. When the maturities of assets and liabilities do not match, a maturity gap takes place and the institution faces interest rate risk. Maturity gap is the difference between the weighted average of the institutions' assets and liabilities (Blaschke ve Diğ., 2001: 12).

Duration Model; duration can be defined as the weighted average of the maturitires of assets and liabilities. If the duration is longer, sensitivity level of the assets and liabilities to the interest rates are higher (Cihak, 2004b: 3).

Duration gap is also defined as the duration difference of assets and liabilities for a bank (Blashke ve Diğ., 2001: 14).

\subsubsection{Exchange Rate Risk}

Exchange rate risk measures effects of the changes of exchange rate on the value institutions' assets and liabilities at local currency and also effects on off the balance sheet assets. Exchange rate risk usually occurs in two ways. Direct exchange rate risk is the risk if the financial institution is in foreign exchange net general position. Indirect exchange risk occurs if the borrowers have tendency to insolvency.

\subsubsection{Credit Risk}

Credit risk can be defined as the unexpected losses as a consequence of unexpected changes in credit quality. Credit risk is nowadays one of the most significant risks after many developments in the Banking Sector. Largest source of the credit risk is loans. Corporate bonds with the risk of partner's bankruptcy and over the counter operations are also sources of risk (Cihak, 2004a: 18).

There are two main methods to apply macro prudential stress test for credit risk. First is the method based on loan performance data (for example performing and non-performing 
loans) and the second is methods based on borrowers data (for example, based on the balance sheet or income tables of borrowers).

One advantage of using credit performance data is it is easy for managers to achieve the necessary data. Another advantage is although it is difficult to achieve the data, it is possible to collect them for household sector and all the other sectors.

On the other hand, main disadvantage of the method is the non-performing loans are the lagged indicator of securities.

One group of this method includes the re-classification of the securities. Effect of security re-classification on the capital adequacy ratio is determined after the additional provisions gained from the securities are determined. Second group of methods rely on econometric models including non-performing loans and some macroeconomic variable (interest rates, increases in GDP, increase in terms of trade). Model can be a simple regression model, a vector auto regression model or a structural model. The simple regression model and vector auto regression model are commonly used in this method. Regression models can be built according to sectors or data of financial institutions (to measure the sensitivity of financial institutions to various economic developments). But this way can provide extremely sensitive results for this reason consolidated data should be used to build the model. By this way, parameters from the model can be used for institutional calculations. Same difficulties can occur in the regression method (difficulty to have long term and consistent data of nonperforming loans). Even though long term data is obtained, there can be structural breaks due to a change of the definition of non performing loans or political changes (Cihak, 2005: 433434).

Data of borrowers give advantage by maintaining a linkage between the real sector data and banking sector data to have an extended model. Another advantage of using this data is gaining some helpful data to define the problems of credit portfolio before credit classification.

There are also some disadvantages. It sometime may be difficult to obtain data for households and small corporations. Data of the borrowers is most of the time long range of time (Cihak, 2005: 434).

\section{CONCLUSION}

Strength of banking system both in the developing and the developed countries plays an important role for a countries financial system and also for the stability of the international financial system. So, one of the most important par of the financial system, banking sector should be disciplined, transparent and scientific. Banking sector is one of the most important components of Turkey's economy. How the banking sector will be affected by the fluctuations of the overall economy should be presented both for the financial economy and the real sector economy. Integration of the world economy requires more effective 
precautions against the crisis. Interest rate risk and exchange rate risk are the primary risk that should be taken into account for liberalizes economies.

Stress tests, a tool for risk management, develops severe but possible scenarios about the market, interest, exchange rate, credit and liquidity risks and tries to determine how strong the banking sector is against these scenarios. Stress testing is a more developed method compared to the former risk analysis methods. It reveals more dynamic method than the methods based on historical data analysis. Reactions to different conditions are measured by this method so the possible conditions can be detected before they happen.

Strength of banks to crisis can be measured by non-performing loans. Default is the condition when the borrower fails to fulfill the obligation. Default rate, or default probability, is the ratio of non-performing loans to total loans. Calculation of default rates in these models enables more powerful and straight estimates of credit loss distributions.

Stress test is an important tool especially testing the financial structure of the banks. Although data problem is solved when a credit risk model is used, non-stationary of the variables appears a constraint. However, one should not forget that there is a sensitive and complex relationship between the real variables and financial variables.

\section{REFERENCES}

Altıntaş, Ayhan, (2012), Kredi Kayıplarının Makroekonomik Değişkenlere Dayalı Olarak Tahmini ve Stres Testleri - Türk Bankacıllk Sektörü için Ekonometrik Bir Yaklaşım, G.M. Matbaacıllk ve Ticaret A.Ş., İstanbul.

Arya, P. Om, (2008), Effective Techniques for Stress Testing and Scenario Analysis, GARP: November 4th, India.

Berry, Romain, (2009), Stres Testing Value At Risk, Investment Analytics and Consulting JPMorgan,https://www.jpmorgan.com/tss/General/Stress_Testing_Value-atRisk/1159389400084, (09.06.2012).

Blaschke, Winfrid - Jones, Matthew T.-Majnoni, Giovanni-Peria, Soledad, Martinez, (2001), Stress Testing of Financial Systems: An Overview of Issues, Methodologies, and FSAP Experiences, International Monetary Fund, IMF Working Paper, June 2001,WP/01/88.

Cihak, Martin, (2004a), Stres Testing: A Review Of Key Concepts. Czech National Bank, CNB Internal Research and Policy Note, April 2004. http://www.cnb.cz/en/research/research_publications/irpn/download/irpn_2_2004.pdf, (10.07.2013).

Cihak, Martin, (2004b), Designing Stress Tests for the Czech Banking System. Czech National Bank, CNB Internal Research and Policy Note, April 2004. http://www.cnb.cz/miranda2/export/sites/www.cnb.cz/en/research/research_publicatio ns/irpn/download/irpn_3_2004.pdf, (10.07.2013). 
Cihak, Martin, (2005), Stress Testing of Banking Systems. Czech Journal of Economics and Finance, Vol. 55, No.9-10, pp. 418-440.

Cihak, Martin, (2007), Introduction to Applied Stress Testing, Washington DC : International Monetary Fund, March 2007. IMF Working Paper, WP/07/59. http://www.imf.org/external/pubs/ft/wp/2007/wp0759.pdf, (08.07.2012).

Committee On The Global Financial System (CGFS), (2000), Stress Testıng By Large Financial Institutions: Current Practice and Aggregation Issues. Bank for International Settlements, April 2000. Basel. 1-44. http://www.bis.org/publ/cgfs14.pdf, (16.07.2012).

Cruz, Marcelo, (2002), Modeling, Measuring and Hedging Operational Risk, John Wiley \& Sons Ltd, United Kingdom.

De Bandt, Olivier. - Oung, Vichett, (2004), Assessment of "stress tests" Conducted on the French Banking System, Banque de France Financial Stability Review 5, 55-72. http://www.banquefrance.fr/fileadmin/user_upload/banque_de_france/publications/Re vue_de_la_stabilite_financiere/etud1_1104.pdf, (30.10.2012).

Dowd, Kewin, (2002), An Introduction to Market Risk Measurement, John Wiley \& Sons, Chichester.

Haldane, Andrew.- Hall, Simon. - Pezzini, Silvia. (2007), A New Approach to Assessing Risks to Financial Stability, Bank of England Financial Stability Paper, 2, http://www.bankofengland.co.uk/publications/Documents/fsr/fs_paper02.pdf, (9.09.2012).

Jones, Mathew, T.- Hilberts, Paul - Slack, Graham, (2004), Stress Testing Financial Systems: What to Do When the Governor Calls. IMF Working Paper, WP/04/127, July 2004. http://www.imf.org/external/pubs/ft/wp/2004/wp04127.pdf, (08.01.2012).

Önalan, Ömer, (2003), Finansal Risk Yönetiminde Ekstrem Değer Teorisi, Marmara Üniversitesi, İ.̇̇.B.F. Dergisi, Cilt 18, Sayı 1, ss. 423-437.

Saunders, Anthony, (2000), Financial Institutions Management: A Modern Perspective, (3. Bask1), McGraw-Hill, Boston.

Schinasi, Garry, (2004), Defining Financial Stability, IMF Working Papers, WP/04/187, http://www.imf.org/external/pubs/ft/wp/2004/wp04187.pdf, (08.05.2012).

Sorge, Marco, (2004), Stress-Testing Financial Systems: An Overview Of Current Methodologies, Monetary and Economic Department, BIS Working Papers 165, Bank for International Settlements, http://www.bis.org/publ/work165.pdf, (08.07.2012).

Türkiye Cumhuriyeti Merkez Bankası. (2005), Finansal İstikrar Raporu, Sayı 1, Ankara, http://www.tcmb.gov.tr/yeni/evds/yayin/finist/finist.php, (10.10.2012). 
Quagliariello, Mario, (2009), Macroeconomic Stres Testing: Definitions And Main Components In Stress-Testing The Banking System, Quagliariello, M. (Editör). Cambridge University Pres, Cambridge.

Vinals, Jose, (2012), Macrofinancial Stres Testing-Princeples and Practices, IMF, Monetary and Capital Markets Department, http://www.imf.org/external/np/pp/eng/2012/082212.pdf, (07.07.2013). 